\title{
Bolonia y la aculturación profesional
}

\author{
Albert Oriol Bosch
}

La formación necesaria de un médico requiere algo más que la adquisición de conocimientos formales y habilidades clínicas, precisa también que se produzca una transformación personal que podemos denominar de socialización secundaria o aculturación.

Algunos autores, como Hafferty [1], serían muy críticos con la 'o' utilizada entre socialización secundaria y aculturación, alegando que demuestra cierta confusión entre dos conceptos bien distintos. Sin embargo, entendemos que ambos términos se corresponden con las distintas visiones del proceso transformacional que se tiene desde las perspectivas de la sociología y de la antropología, dos áreas del conocimiento que lamentablemente están ausentes en la educación médica de nuestras latitudes.

Para el pensamiento dominado por un reduccionismo científico positivista o por un relativismo moral libertario, es fácil que repugne esta visión de la educación médica transformacional del individuo y que sea tildado de 'lavado de cerebro'. Ello comporta ignorar que entre el ciudadano lego en medicina -es decir, poseedor tan sólo de los conocimientos generales cada vez más extensos al alcance de la población- y un profesional de la medicina deben existir diferencias esenciales, más allá del conocimiento especializado. Esta transformación se forja en el largo proceso formativo, gracias a la potente motivación de quien aprende a convertirse en médico. Aun cuando el conseguirlo viene determinado por su capacidad para asumir las exigencias establecidas, es fruto de un deseo inherente en el candidato y no impuesto por el sistema. Nadie está obligado a ser médico, tal y como lo ha venido configurando la sociedad a través del pacto social con la profesión.

Las creencias que justifican que el sistema formativo no debe interesarse por el ámbito de los valores que conforman las actitudes, los patrones culturales (que institucionalizan las conductas aceptables) o las relaciones sociales que las juzgan resultan, pues, injustificadas e inaceptables.

William M. Sullivan [2], en una buena imagen del proceso de aculturación, nos dice que la transformación durante el proceso formativo no debe ser

\section{Bologna and the professional acculturation}

The education needed to nurture a physician requires much more than the acquisition of formal knowledge and clinical skills. It also requires a personal transformation that can be called secondary socialization or acculturation.

Some authors, like Hafferty [1] would very much criticize the 'or' used between secondary socialization and acculturation, adducing that it shows a certain confusion between different concepts. Nevertheless, it is possible to understand that they correspond to the different views of the transformational process that occurs in the education of physicians, as seen from the sociological and anthropological perspectives, two fields of knowledge unfortunately absent in the medical education at home.

The vision of medical education as a personal transformation of the learner may be considered as 'brain washing', and therefore rejected by those whose way of thinking conforms either to a strict reductionism of scientific positivism or to a libertarian moral relativism. But ignoring the personal transformation that occurs along the making of a physician means to also ignore the differences between a lay person, someone that possesses the every day general knowledge on health and diseases, and a professional physician. The evident differences among them are not only restricted to the possession of the specialized knowledge of the medical sciences or the required clinical skills to practice. The difference is also found in the specific ethos of the physicians that evolves in a personal transformation during the learner's long formative period fueled by her desire to become a physician. Although the successful accomplishment of this transformational process by the learner depends on her capacity to conform to the established requirements, it is something inherently depending on the learner's desire to become a physician, and not being imposed by the system, since nobody forces anyone to become one. But if someone wants to be recognized as a physician, she has to fulfill the requirements that have evolved over time in accordance to the implicit agreement of the profession with society.
Presidente de la Fundación Educación Médica.

E-mail: aoriolb@terra.es

(c) 2011 Educación Médica 
tanto consecuencia de las fuerzas externas impuestas (como sería el caso del ceramista cuando modela la arcilla para conseguir un jarrón) como resultado de las fuerzas internas, del deseo y el esfuerzo por alcanzar un fin (como en el caso del culturista que, con entrenamiento y esfuerzo, desarrolla su musculatura hasta modelar un cuerpo atlético).

Es momento de preguntarse hasta qué punto el proceso de Bolonia cuenta con la energía suficiente y la orientación adecuada para modificar la docencia en las facultades de medicina. ¿Asumirán estas facultades que su responsabilidad social les obliga a ir más allá de la formación digna de técnicos en el diagnóstico, tratamiento, rehabilitación y prevención de enfermedades? ¿Intentarán activar un proceso docente encaminado a formar profesionales médicos deseosos de atender el principio de que 'quien sufre la enfermedad es el paciente'? Asumirlo e intentarlo no debe ser una actividad meramente declarativa, es ponerse y arremangarse.

Bibliografía / References

1. Hafferty FC. In search of the lost cord: professionalism and the medical education's hidden curriculum. In Wear D, Bicker J, eds. Educating for professionalism: creating a culture of humanism in medical education. Iowa: University of Iowa Press; 2000. p. 11-34.

2. Sullivan WM. Teaching medical professionalism. In Cruess RL, Cruess SR, Steinert Y, eds. Teaching medical professionalism. New York: Cambridge University Press; 2009. p. IX-XVI.
There seems to be no reason to continue upholding beliefs that justify the carelessness condoned by an educational system as it relates to its consideration of the professional values that support attitudes that are expressed in the expected professional behaviors that conform to the cultural patterns of society.

William M. Sullivan [2] describes metaphorically the acculturation occurring during the educational process not so much as a transformation caused by external pressures, as it would be in the case of a sculptor working with clay, but rather, as a transformation derived from the internal desire and the personal effort, in a way similar to the athlete that develops the body musculature trough energetic exercises.

It is time to ask if the Bologna process will mobilize enough energy and set the proper direction to produce the needed teaching and learning processes changes at our Medical Schools. Will Medical Schools attend to their social responsibility that now demands from them to produce something more that experts in diagnosis, treatment, rehabilitation and prevention of diseases? Will they be able and willing to activate new educational approaches in order to produce professionals of healing, physicians willing to care for the sufferers of diseases, the patients? An answer in the affirmative should not be reduced to words, but rather a hands on institutional response! 